УДК 598.2./9.(477.75)

\title{
СОВРЕМЕННОЕ СОСТОЯНИЕ РАРИТЕТНОЙ ОРНИТОФАУНЫ КАРАДАГСКОГО ЗАПОВЕДНИКА
}

\author{
Бескаравайный М.М.
}

\begin{abstract}
ФГБУН «Карадагская научная станияия им. Т.И. Вяземского - природный заповедник РАН», Феодосия, Российская Федерация, E-mail: karavay54@mail.ru
\end{abstract}

Рассматривается современный состав раритетного компонента орнитофауны Карадагского заповедника и состояние видов, внесенных в Красные книги РФ и Крыма. Исследования проводились на заповедной территории и акватории и прилегающей к ним километровой зоне суши и моря. Проанализированы как новые (после 2005 г.) так и опубликованные данные.

В заповеднике представлен широкий спектр гнездовых и кормовых биотопов, чем обусловлена его ценность, как резервата редких видов. Отмечен 61 вид из указанных красных книг, трофическая и (или) топическая связь с территорией и акваторией заповедника установлена для 45. Гнездится 9 (возможно 10) видов, из них 7 - в скальных биотопах. В настоящее время отсутствуют гнездившиеся ранее могильник, орлан-белохвост и сизоворонка. В XXI в. отмечено появление курганника и повторное гнездование белоголового сипа, рост численности балобана, сапсана и хохлатого баклана, снижение численности сизого голубя. Зимует 23 вида, регулярно - 9: обычны чернозобая гагара, хохлатый баклан, длинноносый крохаль, сизый голубь и желтоголовый королек. Регулярные залеты характерны для черного грифа и белоголового сипа. Исключительно при экстремальных похолоданиях зимуют огарь и черноголовый хохотун. Установлен пролет 49 видов - 37 весной и 26 осенью (регулярно - чернозобая гагара, желтая цапля, коростель, перевозчик, клуша, обыкновенная горлица, обыкновенный зимородок, желтоголовый королек). Не менее 11 видов кочуют в теплое время года.

Ключевые слова: Карадагский заповедник; птицы; редкие виды; гнездование; зимовка; пролет; численность

Одна из основных функций заповедников заключается в сохранении и мониторинге популяций редких видов фауны, в частности птиц. В Крыму актуальность таких исследований обусловлена двумя обстоятельствами: необходимостью регионального изучения редких видов РФ в связи с изменением в 2014 г. государственного статуса полуострова и выходом в свет Красной Книги республики Крым (2015), включающей 68 видов птиц.

Ранее было рассмотрено состояние видов, внесенных во второе издание Красной Книги Украины (1994), обитающих на юго-востоке Крыма (Бескаравайный, 2001) и в Карадагском заповеднике (Бескаравайный, 2004, 2005). Материалы по некоторым из них, включенным в Красную Книгу РФ (2001), содержатся в ряде более поздних публикаций (Бескаравайный, 2008 и др.): отдельные работы, включающие материалы по заповеднику, посвящены хохлатому баклану (Бескаравайный, 2011) и сапсану (Бескаравайный, Цвелых, 2009). В настоящей работе дается оценка современного состояния видов птиц заповедника, внесенных в федеральную ${ }^{1}$ и региональную Красные книги с учетом данных последних лет.

${ }^{1}$ Список объектов животного мира, занесенных в Красную книгу Российской Федерации (по состоянию на 1 сентября 2016 г.) (http://www.mnr.gov.ru/regulatory/detail.php?ID=145272).

(C) М.М. Бескаравайный, 2016

Труды Карадагской научной станции им. Т.И. Вяземского - природного заповедника РАН. - 2016. - Вып. 2 


\section{Материал и методика}

Использованы результаты исследований, проведенных на территории и акватории Карадагского заповедника (2874,2 га, в том числе 809,1 га акватории Чёрного моря), а также в прилегающей к его границам зоне суши и моря шириной приблизительно 1 км. Сбор данных о редких видах осуществлялся в рамках выполнения научной тематики Карадагского заповедника, прежде всего - «Летописи природы». Наряду с уже опубликованными материалами, использованы новые данные, полученные после 2005 г.

Проводилось регулярное обследование гнездовых стаций редких видов, для большинства из которых это скальные формы рельефа. Виды береговых скал (хохлатый баклан, сизый голубь, сапсан) учитывались ежегодно с катера - в гнездовое время и после вылета птенцов (47 учетов, маршрут 7 км). Данные о численности обыкновенной горлицы приводятся на основании обследования древесно-кустарниковых биотопов (95 учетов на маршрутах 1-2 км).

В зимний и миграционные сезоны обследовались прибрежная морская акватория (45 учетов на вдольбереговых маршрутах 2,5-5 км,) и суходольные биотопы (50 учетов на маршрутах 1-3,3 км).

\section{Результаты исследований}

В пределах небольшой площади Карадагского заповедника представлен широкий спектр гнездовых и кормовых биотопов (древесно-кустарниковые, степные, скальные, береговые, прибрежная акватория), чем обусловлена его ценность, как резервата орнитологического разнообразия и в частности раритетного компонента орнитофауны. Основная информация о редких видах птиц, выявленных в заповеднике за время его существования, а также на прилегающей к его границам 1-километровой зоне территории и акватории, приводится в таблице 1.

Таблица 1.

Редкие птицы Карадагского заповедника

\begin{tabular}{|c|c|c|c|c|c|c|c|c|c|}
\hline \multirow{3}{*}{ Вид } & \multicolumn{2}{|c|}{\begin{tabular}{|c|} 
Категория \\
редкости \\
\end{tabular}} & \multicolumn{7}{|c|}{$\begin{array}{c}\text { Характер и регулярность пребывания, } \\
\text { оценка численности }\end{array}$} \\
\hline & \multirow{2}{*}{$\begin{array}{l}\text { КК } \\
\text { РФ }\end{array}$} & \multirow{2}{*}{$\begin{array}{l}\text { КК } \\
\text { РК }\end{array}$} & \multirow{2}{*}{ Гн, $\mathrm{O}$} & \multirow{2}{*}{ Зим. } & \multicolumn{2}{|c|}{ Мигр. } & \multicolumn{3}{|c|}{ Коч. } \\
\hline & & & & & B & $\mathrm{O}$ & $\mathrm{B}$ & $\pi$ & $\mathrm{O}$ \\
\hline Чернозобая гагара - Gavia arctica & 2 & - & - & P IV & P IV & P II & - & H I & - \\
\hline Красношейная поганка - Podiceps auritus & 2 & - & - & Э I & Э I & - & - & - & - \\
\hline Хохлатый баклан - Phalacrocorax aristotelis desmarestii & 2 & 3 & P IV & P IV & - & - & - & - & - \\
\hline Малый баклан - Phalacrocorax pygmaeus & 5 & 3 & - & Э I & - & - & - & Э I & - \\
\hline Желтая цапля - Ardeola ralloides & - & 3 & - & - & P II & H I & - & ?H I & - \\
\hline Каравайка - Plegadis falcinellus & 3 & 2 & - & - & H I (II) & - & - & Э I & - \\
\hline Черный аист - Ciconia nigra & 3 & 1 & - & - & - & $\mathrm{H}(\mathrm{I})$ & - & - & - \\
\hline Краснозобая казарка - Rufibrenta ruficollis & 3 & 2 & - & Э I & - & - & - & - & - \\
\hline Серый гусь - Anser anser & 2 & 2 & - & Э I & Э I & Э (III) & - & - & - \\
\hline Огарь - Tadorna ferruginea & - & 2 & $?$ & $\mathrm{H} \mathrm{I}$ & $\mathrm{H} \mathrm{I}$ & - & - & - & - \\
\hline Серая утка - Anas strepera & 2 & 3 & - & Э*I & Э I & - & - & - & - \\
\hline Белоглазая чернеть - Aythya nyroca & 2 & 2 & - & Э*I & $\Im^{*} \mathrm{I}$ & - & - & - & - \\
\hline Длинноносый крохаль - Mergus serrator & - & 3 & - & P II & H II & - & - & - & - \\
\hline Скопа - Pandion haliaetus & 3 & 3 & - & - & Э I & Э (I) & - & - & - \\
\hline Степной лунь - Circus macrourus & 3 & 0 & - & - & - & Э*(I) & - & - & - \\
\hline Луговой лунь - Circus pygargus & - & 3 & - & - & $?$ & $\mathrm{H}(\mathrm{I})$ & - & - & - \\
\hline Курганник - Buteo rufinus & 3 & 3 & P I & P I & - & $\mathrm{P}(\mathrm{I})$ & - & - & - \\
\hline Змееяд-Circaetus gallicus & 3 & 3 & ?P I & - & - & $\mathrm{P}(\mathrm{I})$ & - & - & - \\
\hline
\end{tabular}


продолжение табл. 1

\begin{tabular}{|c|c|c|c|c|c|c|c|c|c|}
\hline Большой подорлик - Aquila clanga & 2 & - & - & - & - & $\ni *(I)$ & - & - & - \\
\hline Малый подорлик - Aquila pomarina & 3 & - & - & - & - & $\mathrm{H}^{*}(\mathrm{I})$ & - & - & - \\
\hline Могильник - Aquila heliaca & 2 & 2 & $!$ & Э (I) & - & $\mathrm{H}(\mathrm{I})$ & - & Э (I) & - \\
\hline Беркут - Aquila chrysaetos & 3 & 3 & - & Э*(I) & - & - & - & - & - \\
\hline Орлан-белохвост - Haliaeetus albicilla & 5 & 0 & $!$ & $\mathrm{H}(\mathrm{I})$ & - & Э (I) & - & - & - \\
\hline Стервятник - Neophron percnopterus & 1 & 1 & - & - & - & Э (I) & - & & - \\
\hline Черный гриф - Aegypius monachus & 2 & 3 & - & P I-II & - & - & $\mathrm{H} \mathrm{I}$ & $\mathrm{H} \mathrm{I}$ & $\mathrm{H} \mathrm{I}$ \\
\hline Белоголовый сип - Gyps fulvus & 3 & 3 & Э I & P I-II & - & - & $\mathrm{H} \mathrm{I}$ & $\mathrm{H} \mathrm{I}$ & $\mathrm{HI}$ \\
\hline Балобан - Falco cherrug & 1 & 5 & $\mathrm{P} \mathrm{I}$ & $\mathrm{HI}$ & - & - & - & - & - \\
\hline Сапсан - Falco peregrinus brookei & 3 & 5 & $\mathrm{P}$ I & $\mathrm{P} \mathrm{I}$ & - & - & - & - & - \\
\hline Кобчик - Falco vespertinus & 3 & - & - & - & $\mathrm{H} \mathrm{I}$ & Э I & - & ?Э I & - \\
\hline Красавка - Anthropoides virgo & 2 & 2 & - & - & Э I & - & - & - & - \\
\hline Коростель-Crex crex & - & 2 & - & - & $\mathrm{P}+$ & $\mathrm{P}+$ & - & - & - \\
\hline Дрофа-Otis tarda & 2 & 2 & - & Э I & Э I,(III) & - & - & - & - \\
\hline Авдотка - Burhinus oedicnemus & 3 & 3 & - & - & $\mathrm{H} \mathrm{I}$ & - & - & - & - \\
\hline Морской зуек - Charadrius alexandrinus & 2 & 2 & - & - & Э*I & - & - & - & - \\
\hline Ходулочник - Himantopus himantopus & - & 7 & - & - & H I & - & - & - & - \\
\hline Шилоклювка - Recurvirostra avosetta & 3 & 2 & - & - & $\ni *(\mathrm{III})$ & - & - & - & - \\
\hline Кулик-сорока - Haematopus ostralegus & 3 & 3 & - & - & Э I & - & - & - & - \\
\hline Перевозчик - Actitis hypoleucos & - & 3 & - & - & P II & $\mathrm{H} \mathrm{I}$ & - & $? \mathrm{H} \mathrm{I}$ & - \\
\hline Чернозобик - Calidris alpina & 1 & - & - & Э I & - & - & - & - & - \\
\hline Большой кроншнеп - Numenius arquata & 2 & 3 & - & - & Э (I) & - & - & - & - \\
\hline Большой веретенник - Limosa limosa & 3 & 0 & - & - & Э*I & - & - & - & - \\
\hline Черноголовый хохотун - Larus ichthyaetus & 5 & 3 & - & $\mathrm{H} \mathrm{I}$ & Э (I) & - & - & - & - \\
\hline Клуша - Larus fuscus & 2 & - & - & Э I & P I & $\mathrm{H} \mathrm{I}$ & - & H I & - \\
\hline Чеграва - $\underline{\text { Hydroprogne caspia }}$ & 3 & 3 & - & - & - & Э (I) & - & Э (I) & - \\
\hline Малая крачка - $\underline{\text { Sterna albifrons }}$ & 2 & 3 & - & - & Э (I) & Э (I) & - & - & - \\
\hline Клинтух - Columba oenas & - & 3 & - & Э I & Э I & - & - & - & - \\
\hline Сизый голубь - Columba livia & - & 2 & P II & P IV & - & - & P III & P III & P III \\
\hline Обыкновенная горлица - Streptopelia turtur & 2 & - & P III & - & $\mathrm{P}+$ & $\mathrm{P}+$ & - & - & - \\
\hline Филин - Bubo bubo & 3 & 1 & $? !$ & - & - & - & $? \ni * \mathrm{I}$ & - & - \\
\hline Болотная сова - Asio flammeus & - & 2 & - & Э*I & Э I & $?$ & - & - & - \\
\hline Сизоворонка - Coracias garrulus & 2 & 3 & $!$ & - & $\mathrm{H} \mathrm{I}$ & Э I & - & Э I & - \\
\hline Обыкновенный зимородок - Alcedo atthis & - & 3 & - & Э*I & P I & P I & - & $? \mathrm{H} \mathrm{I}$ & - \\
\hline Красноголовый сорокопут - Lanius senator & - & 3 & - & - & Э I & - & - & - & - \\
\hline Серый сорокопут - Lanius excubitor & - & 3 & - & Э I & - & - & - & - & - \\
\hline Розовый скворец - Sturnus roseus & - & 6 & - & - & H II & - & - & Э II & - \\
\hline Камышовка-барсучок - Acrocephalus shoenobaenus & - & 3 & - & - & $Э+$ & $Э+$ & - & - & - \\
\hline Желтоголовый королек - Regulus regulus & - & 3 & - & P III & $\mathrm{P}+$ & $\mathrm{P}+$ & - & - & - \\
\hline Красноголовый королек - Regulus ignicapillus & - & 5 & - & - & Э I & - & - & - & - \\
\hline Испанская каменка - Oenanthe hispanica & - & 3 & Э I & - & Э I & - & - & - & - \\
\hline Пестрый каменный дрозд - Monticola saxatilis & - & 3 & P I & - & - & Э*I & - & - & - \\
\hline Черноголовая овсянка - Emberiza melanocephala & - & 5 & - & - & Э I & - & - & - & - \\
\hline
\end{tabular}

Условные обозначения. КК РФ - Красная Книга Российской Федерации; КК РК - республики Крым. Характер пребывания: Гн,О - гнездящийся перелетный или оседлый (конкретизация в тексте), Зим - зимующий, Мигр. мигрирующий (В - весной, О - осенью), Коч. - кочующий (В - весной, Л - летом, О - осенью); ! - гнездился на Карадаге до создания заповедника; * - отмечен только на прилегающей к заповеднику территории или акватории; ( ) - над заповедником: связь с территорией или акваторией как правило отсутствует. Регулярность: Р встречается (гнездится) регулярно (ежегодно или почти ежегодно); Н - нерегулярно (в некоторые годы); Э эпизодически (менее 10 встреч за весь период исследований). Оценка численности (особей или пар): I $-<10$; II 10-50; III - 51-150; IV - 151-500; + - численность не поддается определению. 
Более подробные сведения о современном состоянии и динамике численности приводятся для следующих видов: 1) всех гнездящихся (рис. 1); 2) зимующих, мигрирующих и кочующих, которые имеют более или менее регулярную (отмечены более чем в 10 сезонах) трофическую и (или) топическую связь с наземными и водными биотопами заповедника.

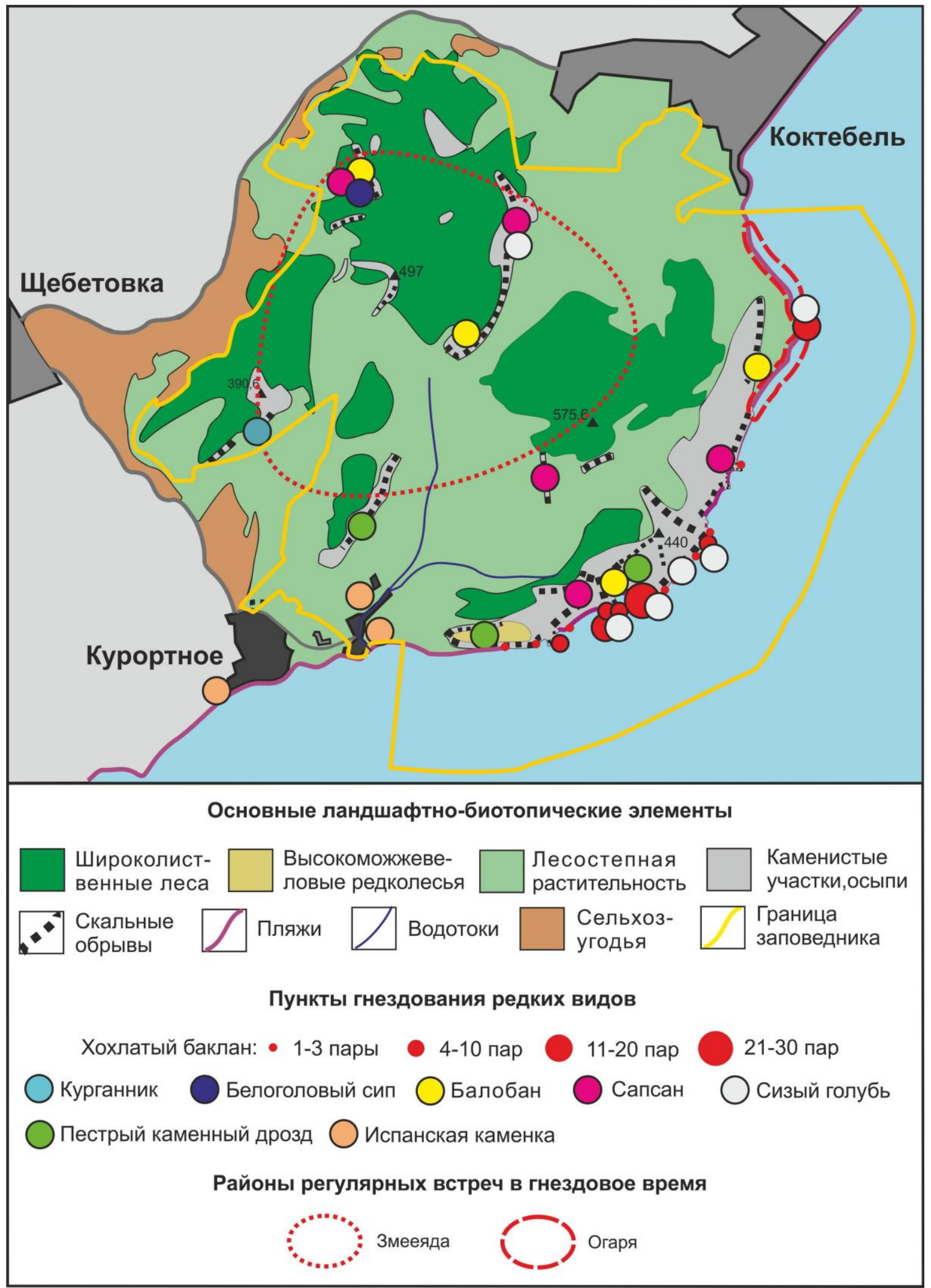

Рис. 1. Места обнаружения гнездящихся редких видов птиц в Карадагском заповеднике. 
Чернозобая гагара - Gavia arctica (L.). Регулярно зимующая, пролетная и спорадически летующая птица Крыма (Костин, 1983) и Карадага: кормовой биотоп прибрежная морская акватория. Во время осеннего пролета (с конца сентября-октября до первой декады ноября) временные скопления включают до 40 птиц. Среднемноголетняя зимняя численность у берегов в последнее десятилетие - 3,8 $\pm 1,2$ (1-9 в разные годы) особей/км, что существенно не отличается от таковой в предыдущие годы (Бескаравайный, Костин, 1999; Бескаравайный, 2008). Весенняя миграция - с середины февраля до третьей декады апреля - середины мая, в марте - апреле численность максимальна: в кормовых скоплениях на акватории - до 200, иногда больше (18.04.2011 г. отмечено 430 особей). Летом встречается не ежегодно в количестве 1-2 (в июне иногда до 6) особей: последние 10 лет не регистрировалась.

Хохлатый баклан - Phalacrocorax aristotelis (L.). В Крыму - оседлый, кочующий у берегов вид (Костин, 1983). Гнездовой биотоп - береговые скальные обрывы (рис. 2) и островки, кормовой - прибрежная акватория моря. У берегов Горного Крыма (м. КиикАтлама - м. Херсонес) гнездится не менее 300 пар (Птицы России...,2011), в Карадагском заповеднике находится самая крупная гнездовая группировка (рис. 3). На фоне установленного здесь в 1979 г. заповедного режима, с начала 80-гг. XX в. численность приобрела тенденцию к росту (Бескаравайный, 2008), превысив в 2005 г. 100, а в 2011 г. 200 пар (см. рис. 3).

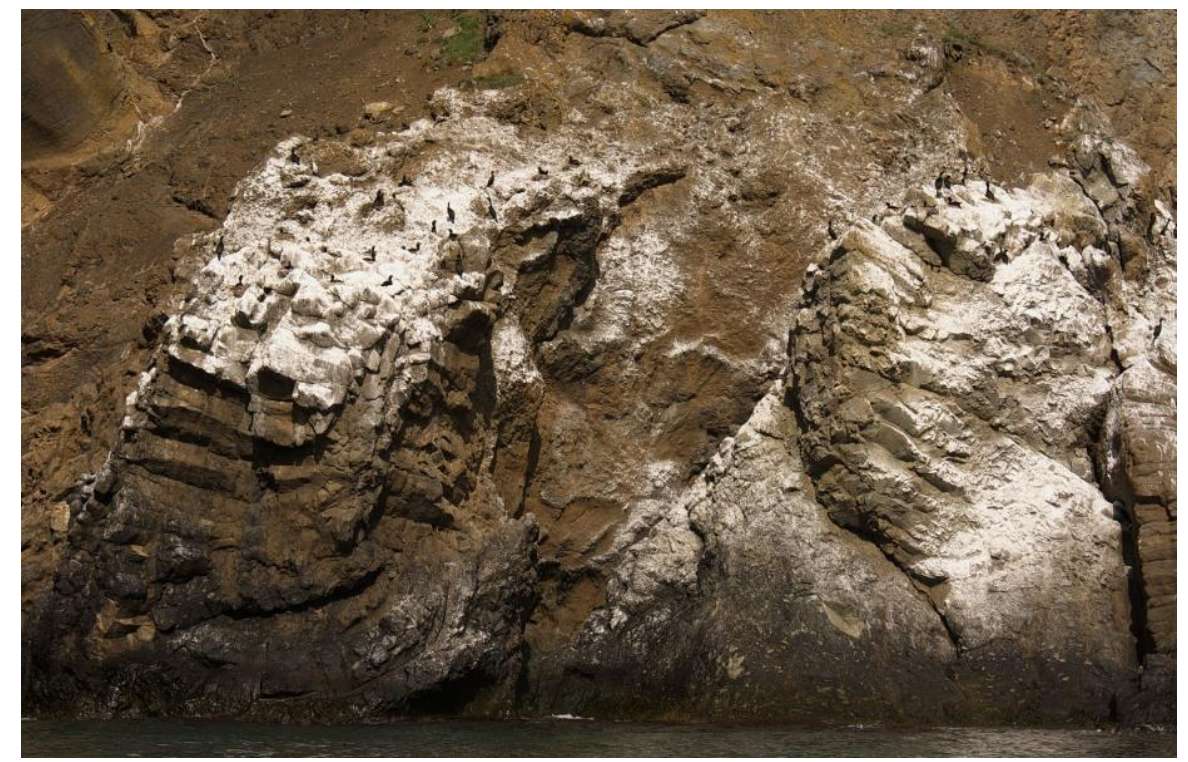

Рис. 2. Гнездовая группа хохлатых бакланов на береговом обрыве в бухте Львиная. Фото М.М. Бескаравайного.

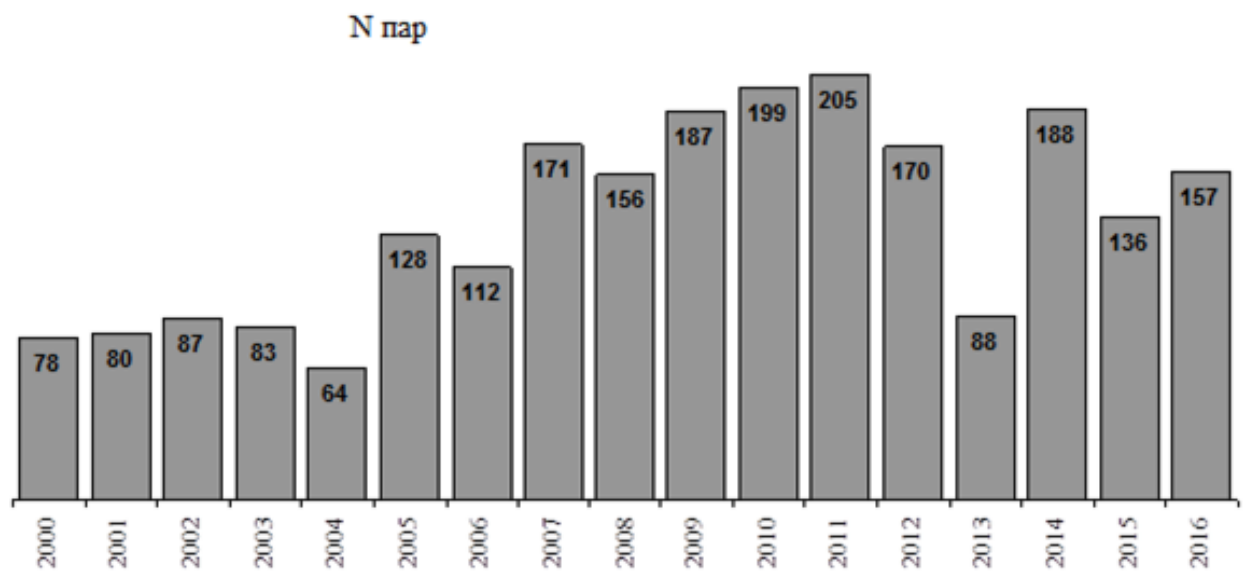

Рис. 3. Многолетняя динамика численности хохлатого баклана в Карадагском заповеднике с начала XXI в.

(C) М.М. Бескаравайный, 2016

Труды Карадагской научной станции им. Т.И. Вяземского - природного заповедника РАН. - 2016. - Вып. 2 
Общая численность после вылета птенцов (конец июня - июль) составляла во второй половине 80-х гг. ХХ в. 110-180, в 2002-2006 гг. - 295-430, в 2008-2011 гг. - 544757 особей.

В послегнездовое время кочует недалеко (25-30 км) от мест гнездования. Среднезимняя плотность в 1981-2000 гг. составляла 1,9-5,6 ос./км, а с начала XXI в и до настоящего времени - 5,2-16,1 ос./км; локальные кормовые скопления насчитывают до 100 птиц.

Желтая цапля - Ardeola ralloides (Scop.). Гнездящаяся (с 1972 г.) и пролетная птица Крыма (Костин, 1983), на Карадаге - только пролетная. Цапли мигрируют над морской акваторией вдоль берегов, задерживаясь в береговой зоне. Весенний пролет - с третьей, реже второй декады апреля до конца мая, наиболее активен в конце апреля - первой половине мая; встречаются до середины июня, возможно летнекочующие - до конца этого месяца (Бескаравайный, 2004, 2008). В заповеднике учитывали до 12, в последнее десятилетие - до 7-8 особей. На осеннем пролете редка: одиночки наблюдались с середины августа до первой декады сентября.

Огарь - Tadorna ferruginea (Pall.). В Крыму - гнездящийся перелетный (Костин, 1983) и зимующий (Бескаравайный, 2001; Семик, Семик, 2002) вид, гнездовая численность сокращается (Костин, 1983).

В апреле - мае 1999-2003 г. 1-2 пары держались на восточном берегу Карадагского заповедника у мыса Мальчин, но достоверного подтверждения гнездования не получено (Бескаравайный, 2008).

Зимует у морских берегов только во время экстремальных похолоданий в количестве 1-3 особей (январь - март 1985, январь 1996 и 2006 гг., февраль, 2012 г.). Весеннепролетные одиночки и пары не ежегодно встречались у Карадага с марта до середины апреля.

Длинноносый крохаль - Mergus serrator L. Оседлый, мигрирующий в пределах полуострова вид (Костин, 1983), на Карадаге - регулярно зимующий.

Зимний биотоп - прибрежная морская акватория. Прилетает в разные годы с третьей декады октября до первой декады декабря, обычно в ноябре (Бескаравайный, 2008). Обычен, но в последние два десятилетия численность снизилась. Так, в 80-х гг. ХХ в. у берегов Карадага зимовало от 3 до 7,5 ос./км, а локальные скопления достигали 70 особей (Бескаравайный, 2001); с 90-х гг. ХХ в. и до последнего времени учитывали не более 3 ос./км. Возможно весеннепролетные птицы встречаются у берегов во 2 половине марта и апреле (до 2,4 ос./км, группы до 13), единично в первой декаде мая.

Курганник - Buteo rufinus (Cretzschmar). В Крыму регулярно гнездится и встречается во все сезоны года со 2 половины 90-х гг. ХХ в., на юго-востоке (у Коктебеля) с 1999 г. (Гринченко и др., 2000). Гнездовой биотоп в горной части полуострова - скальные обрывы. В заповеднике одна пара отмечается на гнездовании с 2006 г., еще две - на соседних территориях (хр. Узун-Сырт, г. Эчкидаг).

Во время осенней миграции в сентябре и октябре немногочислен (группы до 4). Первое зимнее наблюдение в окрестностях заповедника - в 1993 г. (Бескаравайный, 2004), в настоящее время на его территории зимуют 1-2 особи.

Змееяд - Circaetus gallicus (Gm.). В Крыму - гнездящийся пролетный вид (Костин, 1983). Гнездовой биотоп - периферийные зоны высокоствольных лесов и редколесья. В середине - второй половине XX в. гнездился в южной части Карадага на хр. Карагач (Бескаравайный, 2001, 2004). Впоследствии (до 2016 г.) одиночки, пары и молодые птицы регулярно встречались в северной части заповедника, где, вероятно, гнездится и в настоящее время. На окружающих территориях (окрестности поселков Коктебель и Щебетовка, г. Эчкидаг) гнездятся 2-3 пары.

Осенний пролет - в сентябре и первой половине октября, самая поздняя дата 16.10.1996 г. Немногочислен, в некоторые дни учитывали до 5-7 особей. 
Черный гриф - Aegypius monachus (L.). Оседлый, гнездится в горно-лесной части Крыма (Костин, 1983). В заповеднике и ближайших к нему районах кочующие птицы наблюдаются круглогодично. Внутригодовая динамика этих кочевок имеет два хорошо выраженных периода: весенне-летний, совпадающий по времени с гнездовым циклом, и осенне-зимний (рис. 4).

С марта до сентября, когда значительная часть птиц крымской популяции связана с гнездовыми участками, залеты в юго-восточную часть полуострова нерегулярны. В этот период года здесь появляются преимущественно одиночки, реже - группы из 2-3 особей. Минимум регистраций приходится на летние месяцы, когда в гнездах находятся птенцы.

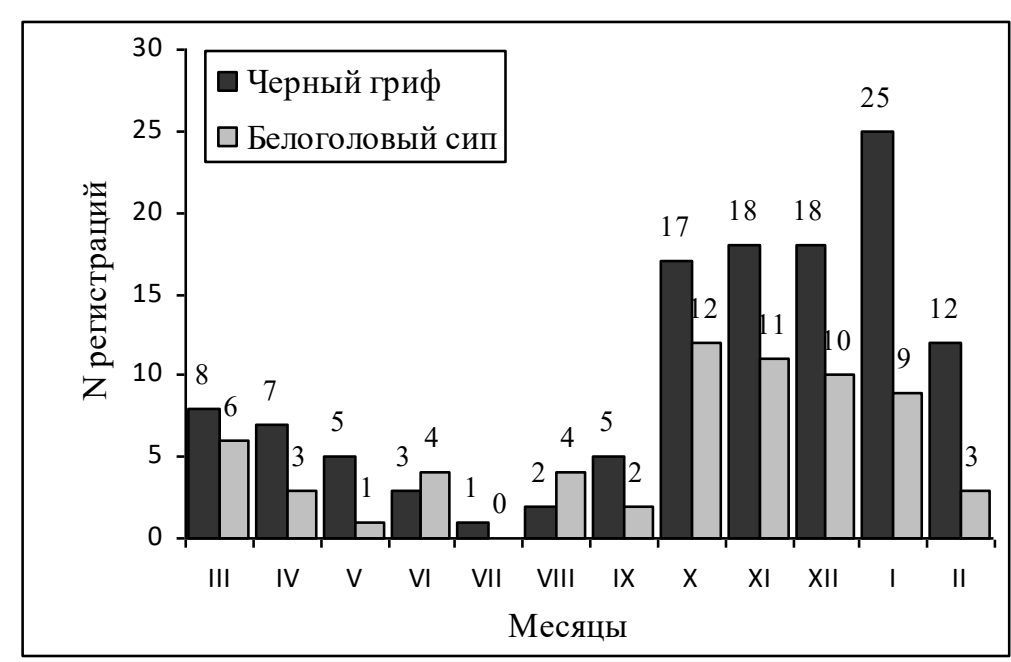

Рис. 4. Распределение регистраций черного грифа и белоголового сипа по месяцам (1982-2016 гг.).

С 1991 г. и до конца XX в. отмечались весенне-летние залеты только одиночных птиц и не ежегодно. С 1999 г., когда был зафиксирован максимум наблюдений (7) (Домашевский, 2002; наши данные) и в продолжение первого десятилетия XXI в. встречи участились, стали появляться группы из 2-3 особей. В последующие годы регулярность кочевок снова снизилась (в 20112015 гг. - только 3 наблюдения, последнее - 3.06.2015 г.).

В негнездовое время (октябрь - февраль) количество залетов резко возрастает. Зимой грифы появляются почти ежегодно, а в январе частота их регистраций максимальна (см. рис. 4). Заметное падение численности происходит во второй половине февраля, когда у птиц начинается гнездовой период.

Регулярность кочевок и численность кочующих в негнездовое время птиц подвержены значительным многолетним колебаниям: обычно за сезон регистрировали до 8 (в одном случае 16) залетов 1-5 (редко 7-10) особей. В период с 1993 до 1998 гг. встречи грифов были редким явлением (до 3 за сезон). Затем их частота приобрела тенденцию к росту, достигнув максимума зимой 2005/2006 гг., когда в заповеднике был падеж кабанов и грифы держались здесь с 22.10.2005 г. до 31.01.2006 г. (до 7 особей). В последующие годы регулярность залетов и численность птиц снова снизились (до 4, редко до 8 наблюдений 1-2 особей).

Белоголовый сип - Gyps fulvus (Hablizl). Оседлая птица Крыма, совершающая кормовые миграции в горно-лесной и предгорной зонах (Костин, 1983). Гнездится в нишах скальных обрывов: Карадаг является крайним восточным пунктом гнездования в Горном Крыму. Здесь известно два случая гнездования: в 1927 г. на г. Святая (Костин, 1983 по данным Г.Д. Серского) и в 2013 г. на г. Икылмак-Кая (Бескаравайный, 2015) (рис. 5).

Внутригодовая динамика кочевок сходна с таковой у черного грифа - хорошо выражены два периода (см. рис. 4).

Кочевки в гнездовое время (с февраля по сентябрь) нерегулярны, количество регистрируемых в это время птиц - 1-4 (27.02.2012 г. учтено 8). С 2009 г., т.е. за 4 года, предшествующих гнездованию в 2013 г., и на следующий после этого год сипы появлялись ежегодно, после чего (в 2015 и 2016 гг.) не наблюдались.

В осенне-зимний период (октябрь - январь) интенсивность кочевок максимальна (см. рис. 4). До 1998 г. встречи были единичными, начиная с зимы 1998/1999 гг.- почти ежегодными. Численность птиц в скоплениях - обычно не более 7. Пик численности (до 12 
особей), обусловленный обилием корма в виде павших кабанов, имел место в 2005/2006 гг., когда сипы встречались в заповеднике с 6 октября, а постоянно - с 22 октября до 16 января.

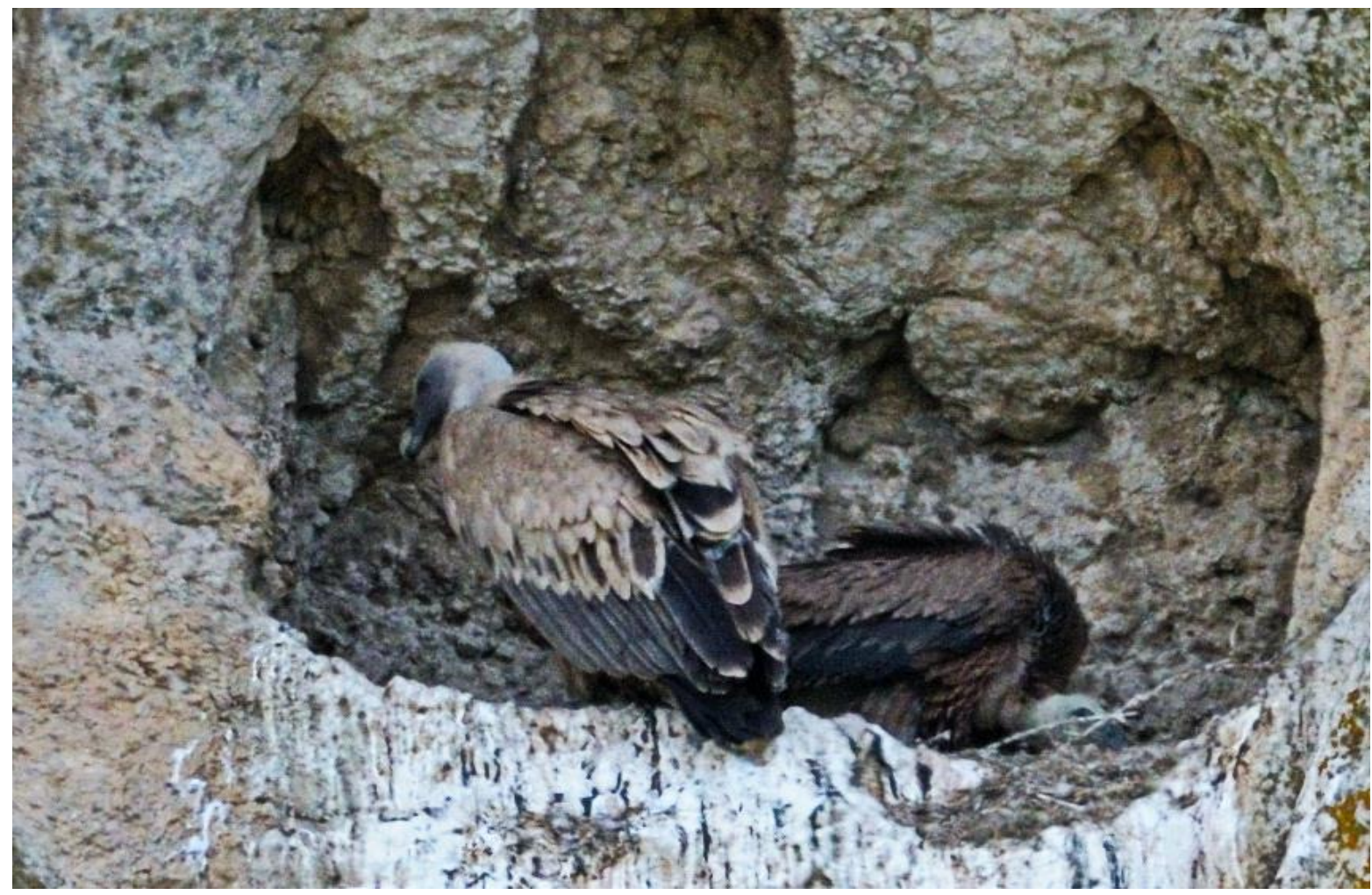

Рис. 5. Белоголовые сипы (взрослый и молодой) у гнезда. Фото Т.Э. Костенко

Балобан - Falco cherrug Gray. В Крыму - гнездящаяся, частично оседлая птица, в последние годы наблюдается рост численности (Милобог и др., 2010); отмечался на осеннем пролете (Домашевский, 2002).

Гнездится на скальных обрывах. До создания и в первые годы существования Карадагского заповедника, единичные пары регистрировались на его территории со второй половины 70-х гг. XX в. (Природа Карадага, 1989; Прокопенко, 1986). С конца XX - начала XXI в. до настоящего времени численность в заповеднике составляет 2-3 (возможно 4) пары. Еще не менее 4 пар выявлено на окружающих заповедник территориях. О частичной оседлости свидетельствуют редкие встречи птиц у мест гнездования в январе и феврале.

Caпcaн - Falco peregrinus Tunst. Гнездится в Крыму, часть местной популяции (F.p. brookei) оседла (Бескаравайный, Цвелых, 2009).

Гнездовой биотоп сходен с таковым у балобана. На Карадаге в гнездовое время отмечался с 1946 г. (фонды Киевского университета) и впоследствии, по архивным данным, в 50-х гг. ХХ в. (Бескаравайный, 2004). После создания заповедника единичные пары регистрировались в 1981 и 1982 гг. на хр. Карагач (Изучение фауны..., 1984) и в 1984 г. - на г. Легенер. С середины 80-х гг. XX в. численность в Крыму начала расти (Гринченко, 1991) и к началу XXI в. составила в заповеднике 4 (возможно 5) пар (примерно 6-7\% крымской популяции). Еще не менее 10 пар гнездятся на окружающих заповедник территориях.

Об оседлости свидетельствуют регулярные зимние встречи птиц и пар у мест гнездования и в радиусе нескольких (до 10) км от них.

Коростель - Crex crex (L.). Гнездящийся (в настоящее время редкий) перелетный и пролетный вид Крыма (Костин, 1983). На Карадаге встречается только на пролете: птицы задерживаются в густой травянистой растительности на открытых участках и среди редколесий. 
Весной пролетает с 3 декады апреля и в продолжение мая (в 2004 г. отмечен 28 марта), максимум наблюдений приходится на 2 декаду мая. До 2010 г. был немногочисленным (в некоторые дни до 1 ос./км, группы до 3). На осеннем пролете встречается не ежегодно, с конца августа до середины сентября. В отличие от Горного Крыма, где известны крупные осенние скопления (Костин, 1983; Гринченко, 2005), в заповеднике немногочислен (в отдельные дни учитывали группы до 3 птиц). После 2010 г. ни весной ни осенью не регистрировался.

Авдотка - Burhinus oedicnemus (L.). В Крыму - гнездящаяся перелетная, в горной части - пролетная птица, численность на гнездовании сократилась (Костин, 1983). В Карадагском заповеднике известна как не ежегодно встречающаяся во время весеннего пролета - с начала апреля до конца мая (Бескаравайный, 2004); задерживается на морском берегу, открытых прибрежных участках, очень редко в редколесьях. До начала XXI в. регистрировалась в незначительном количестве (одновременно не более 2 ос. 1-2 раза за сезон); после 2002 г. известны единичные встречи на южном берегу за пределами изучаемого района.

Ходулочник - Himantopus himantopus (L.). В Крыму гнездящийся перелетный и летующий вид (Костин, 1983), в настоящее время обычен. На юге полуострова (включая Карадагский заповедник) встречается на весеннем пролете с 3 декады марта до 3 декады мая (Бескаравайный, 2008), большинство регистраций - во 2 половине апреля - начале мая. Подходящие биотопы для этого вида в заповеднике отсутствуют: одиночки и стайки до 5 (очень редко до 10) особей пролетают вдоль береговой линии, иногда задерживаясь на морском берегу (рис. 6).

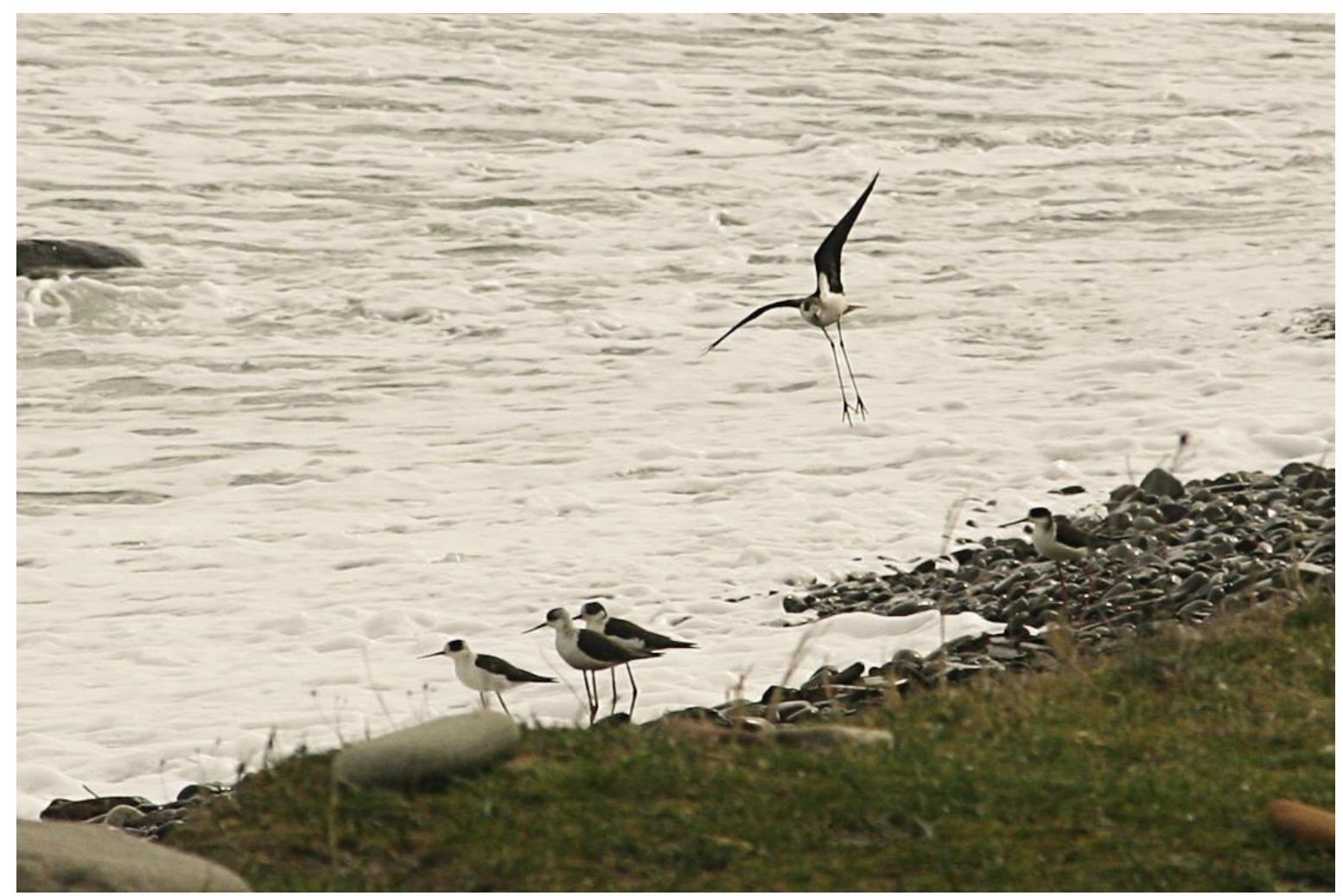

Рис. 6. Весеннепролетные ходулочники на морском берегу. Фото Л.В. Знаменской.

Перевозчик - Actitis hypoleucos (L.). Редкий гнездящийся, перелетный и пролетный вид Крыма (Костин, 1983), в Карадагском заповеднике - пролетный: птицы держатся на морском берегу, где кормятся в зоне прибоя.

Встречается с весны до осени, кроме первой и второй декад июня (рис. 7). Многолетних тенденций динамики численности не выявлено. Большинство первых регистраций приходится на вторую декаду апреля (редко на конец марта), максимум численности - в конце апреля - первой декаде мая (в заповеднике до 20). В третьей декаде

(C) М.М. Бескаравайный, 2016

Труды Карадагской научной станции им. Т.И. Вяземского - природного заповедника РАН. - 2016. - Вып. 2 
мая уже редок. Летом и осенью встречается реже: в конце июня - первой декаде июля единично, в третьей декаде июля в заповеднике держится до 10 птиц. Отлетает в конце августа - первой половине сентября.

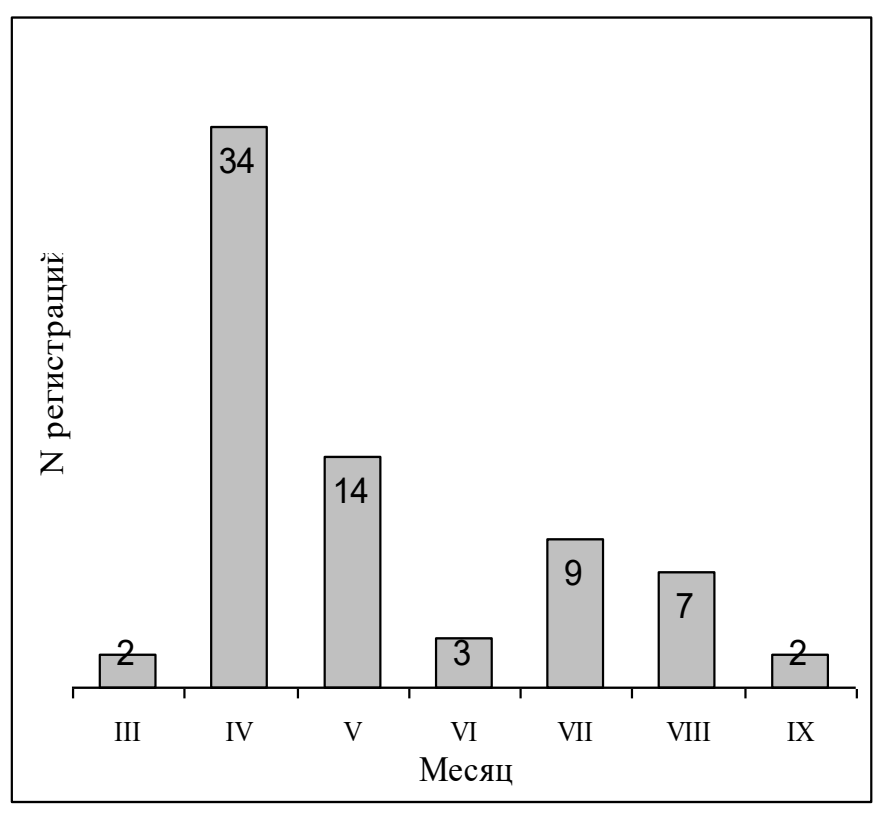

Рис. 7. Распределение регистраций перевозчика в береговой зоне по месяцам.
Черноголовый хохотун - Larus ichthyaetus Pall. В Крыму немногочисленная гнездящаяся перелетная (Костин, 1983), у южных берегов - редкая зимующая (Бескаравайный, 2008) птица: появляется только во время значительных похолоданий, главным образом в январе феврале (Бескаравайный, 2008).

В конце XX - начале XXI вв. У берегов заповедника встречались одиночки, очень редко - до 3-4 птиц (Бескаравайный, 2004). В начале второго десятилетия XXI в. здесь учитывали до 5 (11.02.2012 г.) при общей численности на близрасположенных участках морской акватории - 23 особи (Андрющенко и др., 2012). В это же время впервые вид зарегистрирован и на весеннем пролете в первой декаде марта (Бескаравайный, 2015).

Клуша - Larus fuscus L. В Крыму - многочисленная весеннепролетная птица, изредка встречается летом и осенью (Костин, 1983), очень редко - зимой (Бескаравайный, 2008).

На юго-востоке Крыма и у Карадага весной малочисленна: мигрирующие особи задерживаются у морских берегов с начала марта до конца мая (1-3 регистрации за сезон одиночек и групп до 6 ос.). Летом и осенью (с июня до 3 декады октября) редка (группы до 4 oc.), зимой известна по единственному наблюдению в декабре (Бескаравайный, 2008).

Сизый голубь - Columba livia Gm. Многочисленная оседлая птица Крыма, наблюдается снижение численности (Костин, 1983).

На Карадаге гнездится в нишах и трещинах приморских скальных обрывов и абразионных гротах, единично - на скалах, отдаленных от моря (хр. Сюрю-Кая). Впервые в гнездовое время отмечен здесь в 1946 г. (фонды Киевского университета). В 1952 г. указан Ю.В. Авериным и Г.Д. Серским (архивные данные) как многочисленный гнездящийся вид южной части хр. Береговой. В начале $80-\mathrm{X}$ гг. ХХ в. численность здесь составляла несколько десятков пар, к началу 90-х гг. значительно сократилась (Бескаравайный, 2008), в настоящее время составляет около 10 пар.

С осени до весны голуби регулярно кормятся в разнообразных биотопах вне районов гнездования: дубовых и фисташковых редколесьях (стаи до 120), береговой зоне (до 9 ос./км, стаи до 100), за пределами заповедника - на виноградниках.

Обыкновенная горлица - Streptopelia turtur (L.). Гнездящаяся перелетная и пролетная птица Крыма (Костин, 1983) и Карадагского заповедника.

Гнездовой биотоп - древесная растительность: наиболее обычна на лесных участках (табл. 2). Максимальная численность зарегистрирована в 1983 г. По сравнению с 80-ми годами XX в. численность к началу второго десятилетия XXI в. снизилась более чем вдвое (см. табл. 2). 
Таблица 2.

Динамика численности обыкновенной горлицы в Карадагском заповеднике

\begin{tabular}{|l|c|c|c|c|}
\hline \multirow{2}{*}{ Период } & \multicolumn{2}{|c|}{ Редколесья } & \multicolumn{2}{c|}{ Лесные участки } \\
\cline { 2 - 5 } & $\begin{array}{c}\text { Средняя плотность, } \\
\text { пар/10 га }\end{array}$ & Мax & $\begin{array}{c}\text { Средняя плотность, } \\
\text { пар/10 га }\end{array}$ & Мах \\
\hline $1981-1990$ & $0,3 \pm 0,05$ & 0,6 & $0,7 \pm 0,15$ & 1,9 \\
\hline $1991-2000$ & $0,2 \pm 0,02$ & 0,3 & $0,4 \pm 0,06$ & 0,8 \\
\hline После 2001 & $0,2 \pm 0,02$ & 0,3 & $0,2 \pm 0,04$ & 0,4 \\
\hline
\end{tabular}

Весенний пролет - с середины апреля, в негнездовых биотопах встречалась до 3 декады мая: обычна. Осенью одиночные особи наблюдались до 3 декады сентября.

Сизоворонка - Coracias garrulus L. B Крыму - немногочисленная гнездящаяся перелетная и пролетная птица (Костин, 1983), в Карадагском заповеднике - пролетная и летнекочующая.

Одиночные особи не ежегодно встречались среди разреженной древесной растительности с конца апреля (самая ранняя дата - 25.04.1988 г.) до начала июня. Летом и осенью (самая поздняя дата - 15.09.1981 г.) очень редка. Большинство регистраций (11) приходится на 1981-1990 гг., после 2000 г. - всего две.

Обыкновенный зимородок - Alcedo atthis L. По Костину (1983) пролетный вид Крыма, с 2000 г. известен как гнездящийся (Цвелых, 2001); в Карадагском заповеднике только пролетный.

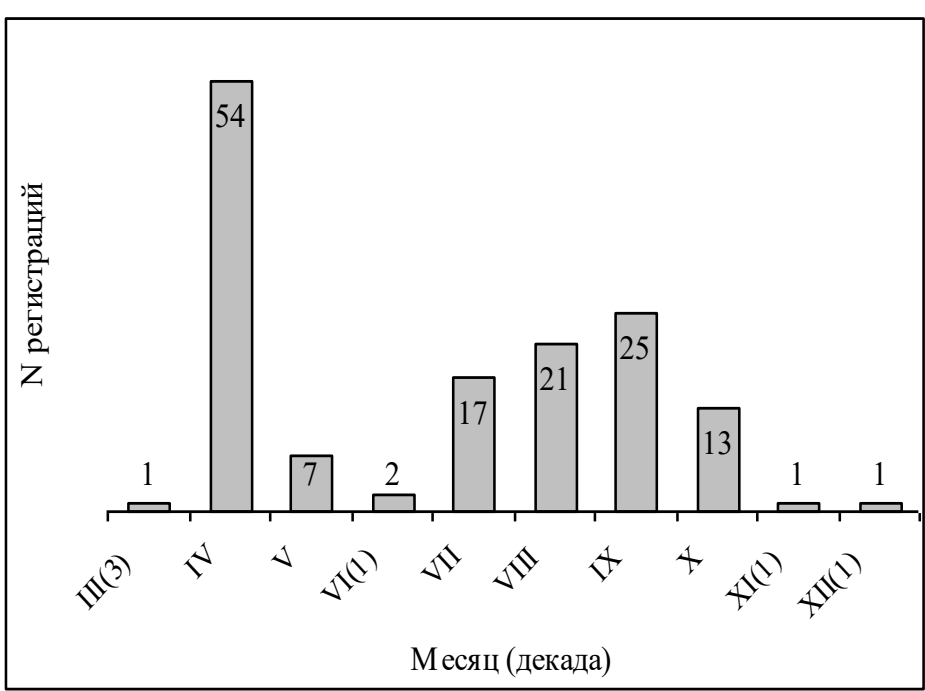

Рис. 8. Распределение регистраций обыкновенного зимородка по месяцам.

В миграционные периоды года держится на морском берегу. Весной появляется в первой половине апреля, очень редко - в последних числах марта (рис. 8). В апреле обычен (до 1 ос./км), в мае и начале июня уже редок. С середины июля численность повышается за счет осенних мигрантов, в августе и сентябре обычен (до 2 ос./км). Встречается до первой половины октября. Позднеосенние и зимние наблюдения единичны (Бескаравайный, 2008). Многолетние тенденции динамики численности отсутствуют.

Розовый скворец - Sturnus roseus (L.). Гнездящаяся перелетная и пролетная птица Крыма (Костин, 1983), в Карадагском заповеднике - весеннепролетная и возможно летнекочующая.

Временными биотопами мигрирующих птиц являются степи и участки разреженной древесной растительности. Встречается не ежегодно, что объясняется нестабильностью гнездовых поселений в Крыму. Пролет начинается во второй половине мая, очень редко - в первой декаде этого месяца (самая ранняя дата - 8.05.2011г.). Численность подвержена значительным колебаниям, ее максимум приходится на третью декаду мая: в заповеднике, включая последнее десятилетие, задерживаются стайки до 40-50 птиц. В июне очень редок.

Желтоголовый королек - Regulus regulus (L.). В Крыму - гнездящийся, зимующий и пролетный вид (Костин, 1983), на Карадаге - зимующий и пролетный.

Биотопы в заповеднике - можжевеловые редколесья и сосновые лесонасаждения, реже - лиственные леса; на прилегающих территориях обычен в парках. Осенний пролет - с 
третьей декады сентября. Зимует регулярно, многолетние изменения численности не существенны. В редколесьях можжевельника высокого на южном склоне хр. Карагач учитывали от 1-2 до 29 ос./км, в сосновых лесопосадках - локально до 6, в дубовом лесу на северном склоне г. Святая - до 8 ос./км. Вероятно весеннепролетные встречаются до конца апреля, очень редко в первой декаде мая.

Испанская каменка - Oenanthe hispanica (L.). Редкий гнездящийся вид Крыма (Кинда и др., 2003); на Карадаге гнездящийся и возможно пролетный.

На гнездовании очень редка. В 1986 г. отмечены 2 пары - на берегу б. Карадагская и на степном участке с наличием глинистых обрывов в юго-западной части заповедника (Кинда и др., 2003); в 1988 г. пара гнездилась в каменной кладке на берегу б. Карадагская. Недалеко (около 1 км) от границы заповедника гнездование отмечено в 2014 г. - в щели каменной постройки на морском берегу в западной части п. Курортное.

Вероятно пролетные птицы регистрировались в береговой зоне в 3 декаде апреля (Бескаравайный, 2008).

Пестрый каменный дрозд - Monticola saxatilis (L.). Немногочисленная гнездящаяся перелетная птица Горного Крыма (Костин, 1983). В Карадагском заповеднике гнездится на скалистых склонах хребтов: отмечался здесь в 1925 и 1952 гг.; в первое десятилетие XXI в. 2 (возможно 3) пары гнездились на хребтах Береговой и Беш-Таш, последний раз - в урочище Хоба-Тепе в 2003 г. (Бескаравайный, 2004). О возможном гнездовании здесь в последние годы свидетельствует наблюдение птицы у границы заповедника (п. Курортное) 13.09.2014 г.

\section{Заключение}

Таким образом, в границах исследуемого района Юго-Восточного Крыма зарегистрирован 61 вид птиц из Красных Книг РФ и республики Крым. Трофическя и (или) топическая связь с территорией и акваторией Карадагского заповедника установлена для 45 видов. Остальные 16 наблюдались в сходных местообитаниях недалеко (не более 1 км) от его границы, или в воздушном пространстве над территорией и акваторией.

Гнездовая часть современного раритетного компонента орнитофауны включает 9 видов (возможно 10 с учетом предположительно гнездящегося змееяда), для 7 из которых гнездовыми стациями являются скальные формы рельефа (хохлатый баклан, курганник, белоголовый сип, балобан, сапсан, сизый голубь, пестрый каменный дрозд). Три вида (могильник, орлан-белохвост и сизоворонка), гнездование которых на Карадаге было известно в середине XX в., в настоящее время здесь отсутствуют. Появление на гнездовании в заповеднике курганника связано с ростом численности этого вида на Украине и появлением его в Крыму в 80-90-х гг. ХХ в. (Гринченко и др., 2000). Одной из возможных причин повторного (после 1927 г.) гнездования белоголового сипа может быть гибель копытных на заповедной территории вследствие браконьерского отстрела ${ }^{2}$. С начала XXI в. прослеживается общая тенденция роста гнездовой численности хохлатого баклана (максимум в 2011 г.) при резком ее снижении в отдельные годы (в 2013 г. - почти в 2 раза: см. рис. 2). На рубеже XX и XXI вв. достигла своего пика численность балобана и сапсана. Имеет место заметное снижение численности сизого голубя и обыкновенной горлицы.

В зимний период на территории и акватории заповедника встречается не менее 23 видов (включая оседлых) и еще 5 - в сходных биотопах недалеко от его границ. Регулярная и продолжительная топическая и трофическая связь с наземными и водными биотопами установлена для 9 видов, из которых обычны и многочисленны 5: чернозобая гагара, хохлатый баклан, длинноносый крохаль, сизый голубь и желтоголовый королек. Регулярные залеты в заповедник во время кормовых кочевок характерны для 2 видов - черного грифа и белоголового сипа. Как временный кормовой биотоп в экстремальные периоды зимы, используют прибрежную акваторию 2 вида - огарь и черноголовый хохотун.

${ }^{2}$ В 2013 г. официально зарегистрирован один случай браконьерства (Летопись природы, 2013). 
На пролете встречается 49 видов (37 весной и 26 осенью). Из них только для 8 связь с биотопами заповедника регулярна (чернозобая гагара, желтая цапля, коростель, перевозчик, клуша, обыкновенная горлица, обыкновенный зимородок, желтоголовый королек). Остальные встречаются эпизодически и в единичном числе, вне заповедной территории и акватории или только в воздушном пространстве над ними. Не менее 11 видов являются кочующими в теплое время года, регулярно и в значительном числе - только сизый голубь.

Благодарности. Выражаем искреннюю благодарность А.Р. Ляндсбергу, Р.С. Кветкову, Т.Э. Костенко, С.П. Прокопенко, О.Г. Розенбергу, любезно предоставившим материалы своих наблюдений, которые были использованы в настоящей статье.

\section{Список литературы}

1. Андрющенко Ю.А., Бескаравайный М.М., Костин С.Ю., Попенко В.М., Прокопенко С.П. О зимовке птиц на юге Крыма в экстремальных условиях зимы 2011/2012 гг. // Бранта: сборник научных трудов Азово-Черноморской орнитологической станции. - 2012. Вып. 15. - С. 140-148.

2. Бескаравайный М.M. Современное состояние и некоторые тенденции динамики численности редких видов птиц юго-восточного Крыма // Беркут. - 2001. - Т. 10, вып.2. - C. 125-139.

3. Бескаравайный М.М. Редкие птицы Карадагского природного заповедника // Карадаг. История, геология, ботаника, зоология (Сб. научн. трудов, посв. 90-летию Карадагской научной станции им. Т.И. Вяземского и 25 -летию Карадагского природного заповедника НАН Украины). Книга 1-я. - Симферополь: Сонат, 2004. - С. 425-444.

4. Бескаравайный М.М. Роль заповедников в сохранении раритетной орнитофауны азовочерноморского побережья Крыма // Заповедники Крыма: заповедное дело, биоразнообразие, экообразование. Материалы III научной конференции 22 апреля 2005 г., Симферополь, Крым. Ч.2. Зоология беспозвоночных. Зоология позвоночных. Экология. - Симферополь: КРА "Экология и мир", 2005. - С. 111-116.

5. Бескаравайный М.M. Птицы морских берегов южного Крыма. Симферополь: «Н.Оріанда», 2008. - 160 с.

6. Бескаравайный М.М. Хохлатый баклан // Птицы России и сопредельных регионов: Пеликанообразные, Аистообразные, Фламингообразные. / Андронов В.А., Ардамацкая Т.Б., Артюхин Ю.Б. и др. Отв. ред.: С.Г. Приклонский, В.А. Зубакин, Е.А. Коблик. М.: Товарищество научных изданий КМК. - 2011. - 602 с.

7. Бескаравайный М.M. Некоторые итоги орнитологических исследований на юго-востоке Крыма в начале XXI века // 100 лет Карадагской научной станции им. Т.И. Вяземского: сборник научных трудов. - Симферополь: Н.Оріанда, 2015. - С. 335-340.

8. Бескаравайный М.М., Костин С.Ю. Структура и распределение зимней гидрофильной орнитофауны Южного берега Крыма // Проблемы изучения фауны юга Украины. Одесса: Астропринт; Мелитополь: Бранта, 1999. - С. 19-33.

9. Бескаравайный М.М., Цвелых А.Н. Распространение, численность и сезонные изменения популяционного состава сапсана (Falco peregrinus, Falconiformes, Falconidae) в Крыму // Зоологический журнал. - 2009. - Т.88, N 6. - С. 1-6.

10. Гринченко А.Б. Новые данные о редких и исчезающих птицах Крыма // Редкие птицы Причерноморья. - Киев-Одесса: Лыбидь, 1991. - С. 78-90.

11. Гринченко А.Б. Современные данные о динамике пролета и ареале гнездования коростеля (Crex crex) в Крыму // Бранта: сборник научных трудов Азово-Черноморской орнитологической станции. - 2005. - Вып. 8. - С. 128-132.

12. Гринченко А.Б., Кинда В.В., Пилюга В.И., Прокопенко С.П. Современный статус курганника в Украине // Бранта: сборник научных трудов Азово-Черноморской орнитологической станции. - 2000. - Вып. 3. - С. 13-26.

13. Домашевский С.В. Наблюдения за осенней миграцией хищных птиц на Крымском полуострове // Беркут. - 2002. - Т. 11, вып. 1. - С. 112-116.

(C) М.М. Бескаравайный, 2016

Труды Карадагской научной станции им. Т.И. Вяземского - природного заповедника РАН. - 2016. - Вып. 2 
14. Изучение фауны и численности наземных позвоночных Карадага (1981-1982) // Карадагский гос. заповедник АН УССР. Летопись природы, 1984. - Т. 1, кн. 1, ч. 5. - 140 с.

15. Кинда В.В., Бескаравайный М.М., Дядичева Е.А., Костин С.Ю., Попенко В.М. Ревизия редких, малоизученных и залетных видов воробьинообразных (Passeriformes) птиц в Крыму // Бранта: сборник научных трудов Азово-Черноморской орнитологической станции. - 2003. - Вып. 6. - С. 25-58.

16. Костин Ю.В. Птицы Крыма. - М.: Наука, 1983. - 240 с.

17. Красная Книга республики Крым. Животные. / отв. ред. д. б. н., проф. С.П. Иванов и к. б. н. А.В. Фатерыга. - Симферополь: ИТ «АРИАЛ», 2015. - 440 с.

18. Красная книга Российской Федерации (животные) / РАН; Гл. редкол.: В.И. ДаниловДанильян и др. - М.: АСТ: Астрель, 2001. - 862 с.

19. Милобог Ю.В., Ветров В.В., Стригунов В.И., Белик В.П. Балобан (Falco cherrug Gray) в Украине и на сопредельных территориях // Бранта: сборник научных трудов АзовоЧерноморской орнитологической станции. - 2010. - Вып. 13. - С. 135-159.

20. Природа Карадага / Бескаравайный М.М., Костенко Н.С., Миронова Л.П. и др. Под ред. Морозовой А.Л. и Вронского А.А. - Киев: Наукова Думка, 1989. - 288 с.

21. Прокопенко С.П. Балобан в Крыму // Изучение птиц СССР, их охрана и рациональное использование. Ч.2. - Л., 1986. - С. 170-171.

22. Семик А.М., Семик Е.А. Редкие виды наземной фауны Опукского природного заповедника и их современное состояние // Заповедники Крыма. Биоразнообразие на приоритетных территориях: 5 лет после Гурзуфа. Материалы II научной конференции. 25-26 апреля 2002 года, Симферополь, Крым. - Симферополь, 2002. - С. 232-236.

23. Цвелых А.Н. Гнездование зимородка в Крыму // Бранта: сборник научных трудов АзовоЧерноморской орнитологической станции. - 2001. - Вып. 4. - С. 146.

Поступила 21 сентября 2016 г. В окончательном виде 30 ноября 2016 г.

\section{MODERN CONDITION OF THE RARE ORNITHOFAUNA OF KARADAGSKY RESERVE Beskaravayny M.M.}

T.I.Vyazemsky Karadag Scientific Station - Nature Reserve of the RAS, Feodosia, Russian Federation, E-mail: karavay54@mail.ru

Modern array of species of rare component of the Karadag reserve ornithofauna and condition of species included into the Red Data Books of the RF and Crimea is considered. Research have been conducted at the protected area and sea aquatorium as well as kilometre zone around them. Both new (after 2005) and the published data are analysed.

Wide spectrum of nesting and forage biotopes are present at the reserve, that is why the reserve is very important for rare bird species support. 61 rare species are noted, trophic and (or) topical connection with reserve territory and water area is established for 45.9 (probably 10) species are nesting here including 7 that nesting on rocky biotopes. Aquila heliaca, Haliaetus albicilla, and Coracias garrulus were nesting in the reserve earlier but not anymore. In XXI century occurrence of Buteo rufinus and re-nesting of Gyps fulvus are indicated; increasing of number of Falco cherrug, Falco peregrines, and Phalacrocorax aristotelis, as well as decreasing of number of Columba livia are noted. 23 species are wintering including 9 that are wintering regularly: Gavia arctica, Phalacrocorax aristotelis, Mergus serrator, Columba livia and Regulus regulus are usual here. Aegypius monachus and Gyps fulvus are regular visitors. Tadorna ferruginea and Larus ichthyaetus are wintering only while cold is extreme. It is indicated migration of 49 species -37 in spring and 26 in autumn, Gavia arctica, Ardeola ralloides, Crex crex, Actitis hypoleucos, Larus fuscus, Streptopelia turtur, Alcedo atthis and Regulus regulus - regularly. About 11 species are wandering in warm season.

Key words: Karadag Reserve; birds; rare species; nesting; wintering; migration; number 